\title{
A Study on the Effects of Dietary Lactose on Ovarian Function and Body Weight in Normal and Obese Female Albino Rats
}

\author{
Romysa A El-Sherbeny, Mahmoud A EI-Gharieb \\ Physiology Department, Faculty of Medicine, Tanta University
}

\begin{abstract}
This work was done to investigate effects of dietary lactose on ovarian function and body weight in normal and obese female albino rats. 36 female albino rats 150$170 \mathrm{gm}$ and 6 weeks old, were divided into two groups:(1)Normal group: composed of 18 rats divided into three subgroups: (A)Control group: received glucose in a dose of $41.9 \mathrm{gm} / 100 \mathrm{gm}$ of standard diet for three months, (B)low lactose diet treated group: received lactose in a dose of $10.5 \mathrm{gm} / 100 \mathrm{gm}$ of standard diet for three months (C)High lactose diet treated group: received lactose in a dose of $41.9 \mathrm{gm} / 100 \mathrm{gm}$ ofthe standard diet for three months.(2)Obese group: composed of 18 rats received high fat diet for one month to induce obesity, then divided into three subgroups: (A) Control group: received glucose in a dose of $41.9 \mathrm{gm} / 100 \mathrm{gm}$ of high fat diet for three months (B)Low lactose diet treated group: received lactose in a dose of $10.5 \mathrm{gm} / 100 \mathrm{gm}$ ofhigh fat diet for three months (C)High lactose treated group: received lactose in a dose of $41.9 \mathrm{gm} / 100 \mathrm{gm}$ of high fat diet for three months. At the end of the experiment, rats were weighed and blood collected from retro orbital plexus for determination of estrogen, progesterone, follicle stimulating hormone (FSH), leptin. Vaginal cytology was done regularly to estimate estrus cycles cyclicity. The results showed significant reduction of body weight, estrogen, progesterone, and leptin in both normal and obese rats, and significant increase of FSH in normal and obese rats. Vaginal cytology showed disturbed and irregular estrus cycles. It can be concluded that, administration of lactose in low and high doses for long periods can affect the ovarian function, and caused reduction of body weight due to galactose content. It is recommended that, women with galactosemia and infertility must assess their galactose level which may be the cause of infertility.
\end{abstract}

\section{INTRODUCTION}

Milk contains nutrients necessary for the growth of mammals, and it is the sole food utilized for quiet long period after birth. Most milk consumed by humans is cow's milk, and most dairy products are processed from cow's milk, that contain abundant calcium, which is likely to be lacking in daily life, and the absorbability of calcium from milk product is high ${ }^{(\mathbf{1})}$. Milk and dairy products also contain other nutrients in addition to calcium and used for the prevention of osteoporosis ${ }^{(2)}$. The antiobesity effects of milk and dairy products are due to their calcium content ${ }^{(3)}$. In addition to calcium, the conjugated linoleic $\operatorname{acid}^{(4)}$ and 
leucine ${ }^{(5)}$ are components of milk and dairy products with antiobesity action. Milk contains $4.4 \%$ lactose that accounts for $99.8 \%$ of saccharides and $40 \%$ of the total solids in milk. The biological effects of lactose are including the promotion of calcium absorption and improvement of bone metabolism ${ }^{(\mathbf{6})}$ lactose consists of one glucose molecule and one galactose molecule, which is the primary carbohydrate in milk. The toxic effects of galactose or its metabolites were experienced by individuals who have glactosemia within the ovary ${ }^{(7)}$. Galactose is also important in the metabolism of healthy ovarian functions, which manifested by the relative abundance of galactose metabolizing enzymes in the ovarian tissue $^{(\mathbf{8})}$. Subsequently the health problems which affect women concerning high dietary galactose, might increase the risk of ovarian cancer or accelerate the age of onset of ovarian failure ${ }^{(\mathbf{9})}$. Epidemiological data have suggested that, an earlier age of menopause can be associated with galactose intake, especially in women who have partial deficiencies of the transferase enzyme ${ }^{(\mathbf{1 0})}$. It was demonstrated in some women with increased levels of follicle stimulating hormone and an associated increase of galactose consumption early menopause irrespective of transferase activity ${ }^{(\mathbf{1 1})}$ Obesity, diabetes, hypertension and hyperlipidemia are independent risk factors of cardiovascular disorder. Obesity is considered to be the main pathological cause of metabolic syndrome ${ }^{(\mathbf{1 2})}$. Insulin, leptin and thyroid hormone are not only important metabolic hormones, but also are recognized as signal linking nutrition and growth, development and reproduction ${ }^{(\mathbf{1 3})}$.

The aim of the present study was to investigate the effect of high and low lactose diet on ovarian functions in normal and obese female albino rats.

\section{MATERIALS \& METHODS}

36 female albino rats weighting 150-170gm and 6 weeks old. Rats were pair housed at room temperature and had free water access. All control and treatment diets were prepared and remained standard ${ }^{\mathbf{( 1 4 )}}$ throughout the experiment with exceptions of glucose, lactose and fat content. The rats were divided into two groups each containing 18 rats.

1- Normal group: was divided into three subgroups each containing 6 rats

a-Control group: received standard diet with glucose (Sigma) 41.9 $\mathrm{gm} / 100 \mathrm{gm}^{(8)}$. of the diet for three months.

b-Low lactose diet treated group: received standard diet with lactose (Sigma)10.5 gm /100gm (14) of the diet for three months.

c-High lactose diet treated group: received standard diet with lactose $41.9 \mathrm{gm} / 100 \mathrm{gm}$ of the diet for three months.

2- Obese group: received high fat diet composed of $70 \%$ fat, $20 \%$

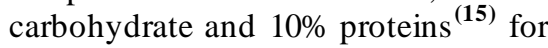
one month to induce obesity with regular weighing of rats.

Rats were divided into three subgroups each contained 6 rats.

a-Control obese group: received high fat diet with glucose 41.9 $\mathrm{gm} / 100 \mathrm{gm}$ of the diet for three months. 
b-Low lactose treated obese group: received high fat diet with lactose $10.5 \mathrm{gm} / 100 \mathrm{gm}$ of the diet for three months.

c-High lactose treated obese group: received high fat diet with lactose $41.9 \mathrm{gm} / 100 \mathrm{gm}$ of the diet for three months.

At the end of the experimental period, rats were fasted overnight, weighed and blood samples were collected from retro-orbital plexus and sera were separated for determination of:

Serum estrogen by the method of Ismail et al ${ }^{(\mathbf{1 6})}$.

Serum progesterone by the method Ismail et al ${ }^{(16)}$.

Follicle stimulating hormone (FSH) by the method of Kulin and Santer ${ }^{(\mathbf{1 7})}$. Serum leptin by the method of Spayd et al. ${ }^{(18)}$.

Vaginal cytology: was assessed five days per week The vaginal smears were stained and examined ${ }^{(\mathbf{1 9})}$. Rats that exhibited at least 3 consecutive 4 or 5 days/cycle were considered to have regular cycles.

\section{Statistical analysis:}

All results were expressed as mean values \pm standard deviation (SD). Mean values of different groups were compared using a one way analysis of variance. Mean value of $\mathrm{P}<0.05$ was accepted to be a significant difference.

\section{RESULTS}

The results of the present study are shown in table (1):

\section{Serum level of estrogen:}

The results showed significant reduction of serum estrogen in normal female received low and high lactose diet compared with the control, $\mathrm{P}<0.05$. Also, there was significant reduction of serum estrogen level in obese rats treated by low or high lactose diet compared with the control, $\mathrm{P}<0.05$, Fig (1).

Serum progesterone level:

The results showed significant reduction of serum progesterone level in normal rats treated by low and high lactose diet compared with the control, $\mathrm{P}<0.05$. Also, there was significant reduction of serum progesterone in obese rats treated by low and high lactose level compared with the control, $\mathrm{P}<0.05$, Fig. (2).

Serum FSH level: The results showed significant increase of serum FSH level in normal rats treated by low and high lactose diet compared with the control, $\mathrm{P}<0.05$. Also, there was significant increase in serum FSH level in obese rats treated by low and high lactose diet compared with the control, $\mathrm{P}<0.05$, Fig (3).

\section{Serum leptin level:}

The results showed significant reduction of serum leptin level in normal rats treated by low and high lactose diet compared with the control, $\mathrm{P}<0.05$. Also, there was significant reduction of serum leptin level in obese rats treated by low and high lactose diet compared with the control, <.05, Fig(4).

\section{Body weight:}

The results showed significant reduction of body weight in normal rats treated by low and high lactose diet compared with the control, $\mathrm{P}<0.05$. Also, obese rats treated by low and high lactose diet showed significant reduction of the body weight compared with the control, $\mathrm{P}<0.05$, Fig (5) 
Vaginal cytology:

At the beginning of the experiment, all rats had regular estrous cycles. Afterwards, the incidence of irregular cyclicity appeared and increased. The high lactose treated group of normal and obese rats, had obvious irregularity more than low diets compared with the control. Mild irregularity had been occurred in low lactose treated group.

Table (1): Effects of low and high lactose diet on serum estrogen, progesterone, FSH, leptin, and body weight in normal and obese female albino rats (mean 6 \pm SD)

\begin{tabular}{|l|l|l|l|l|l|l|}
\hline \multirow{2}{*}{ Parameter } & \multicolumn{4}{|l|}{ Normal female rate } & \multicolumn{3}{l|}{ Obese female rates } \\
\cline { 2 - 7 } & Control & Low & High & Control & Low & High \\
\hline Estrogen pg/ml & $63.3 \pm 096$ & $60.8 \pm 1.17^{*}$ & $59.3 \pm 0.99^{*}$ & $56.8 \pm 1.23$ & $53.01 \pm 1.12^{*}$ & $51.3 \pm 0.75^{*}$ \\
\hline $\begin{array}{l}\text { Progesterone } \\
\text { pg/ml }\end{array}$ & $12.5 \pm 0.55$ & $10.2 \pm 0.73^{*}$ & $7.9 \pm 0.33^{*}$ & $10.08 \pm 0.96$ & $8.5+0.6^{*}$ & $7.05 \pm 0.43^{*}$ \\
\hline FSH IU & $0.468 \pm 0.01$ & $0.696 \pm 0.03^{*}$ & $0.851 \pm 0.03^{*}$ & $0.545+0.01$ & $0.705 \pm 0.05^{*}$ & $0.941 \pm 0.02^{*}$ \\
\hline Leptin ng/ml & $33.2 \pm 1.07$ & $21.7 \pm 2.16^{*}$ & $10.8 \pm 1.53^{*}$ & $42.6 \pm 1.36$ & $25.4 \pm 1.39^{*}$ & $14.3 \pm 1.6^{*}$ \\
\hline Body weight gm & $159.6 \pm 7.11$ & $150.1 \pm 4.91^{*}$ & $140.8 \pm 5.63^{*}$ & $235 \pm 7.07$ & $218.6 \pm 4.71^{*}$ & $200.5 \pm 7.12^{*}$ \\
\hline
\end{tabular}

$*=$ Denotes statistical significance

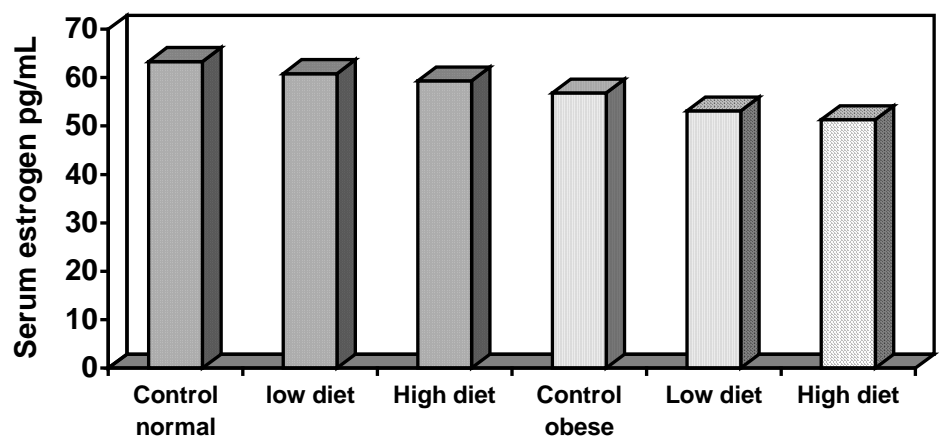

Fig. (1): E ffect of low and high lactose diets on serum estrogen $(\mathrm{pg} / \mathrm{ml})$ level in normal and obese female albino rats 


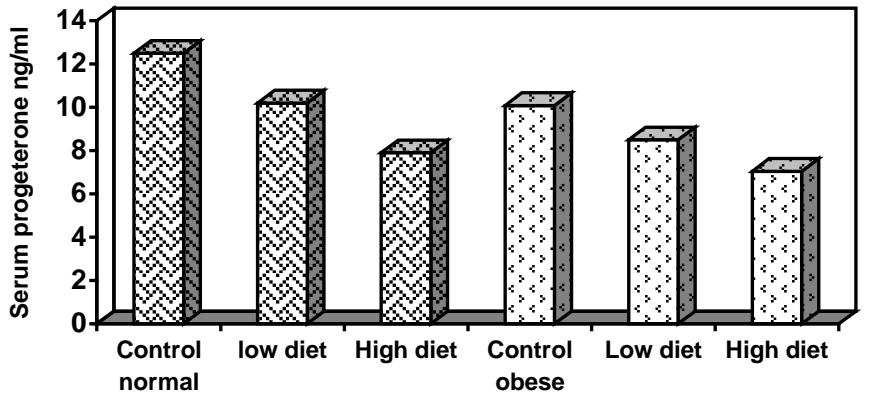

Fig. (2): Effect of low and high lactose diets on serum progesterone (pg/ml) level in normal and obese female albino rats

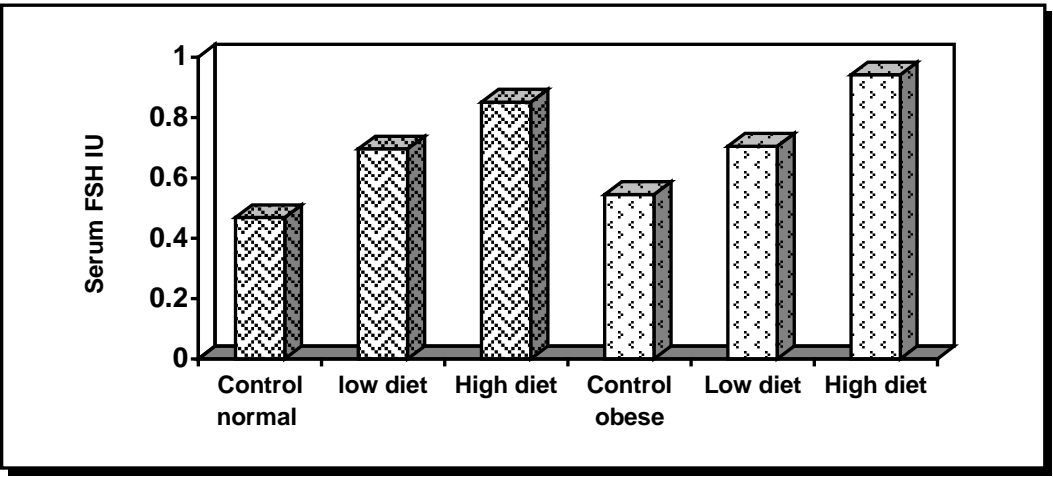

Fig. (3): Effect of low and high lactose diets on serum FSH (IU) level in normal and obese female albino rats

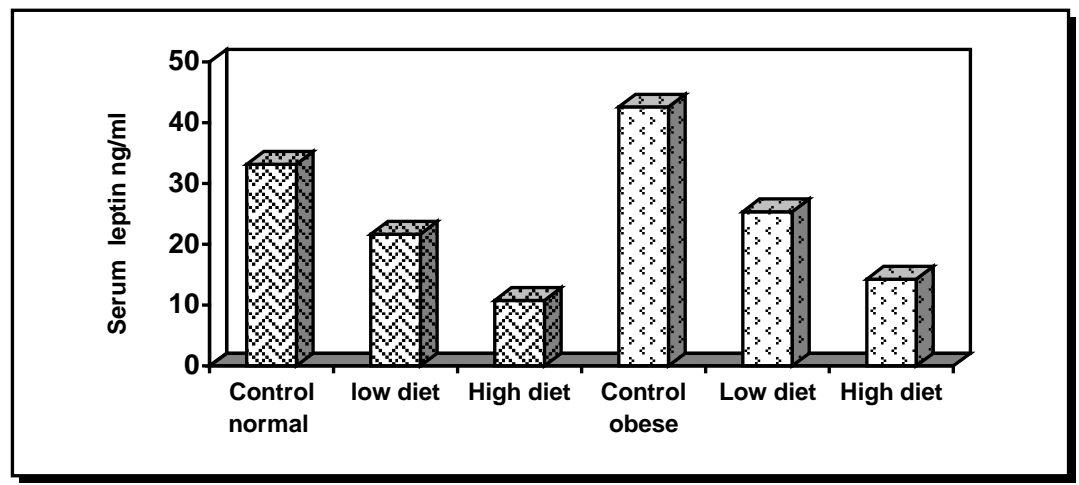

Fig. (4): E ffect of low and high lactose diets on serum leptin (ng/ml) level in normal and obese female albino rats 


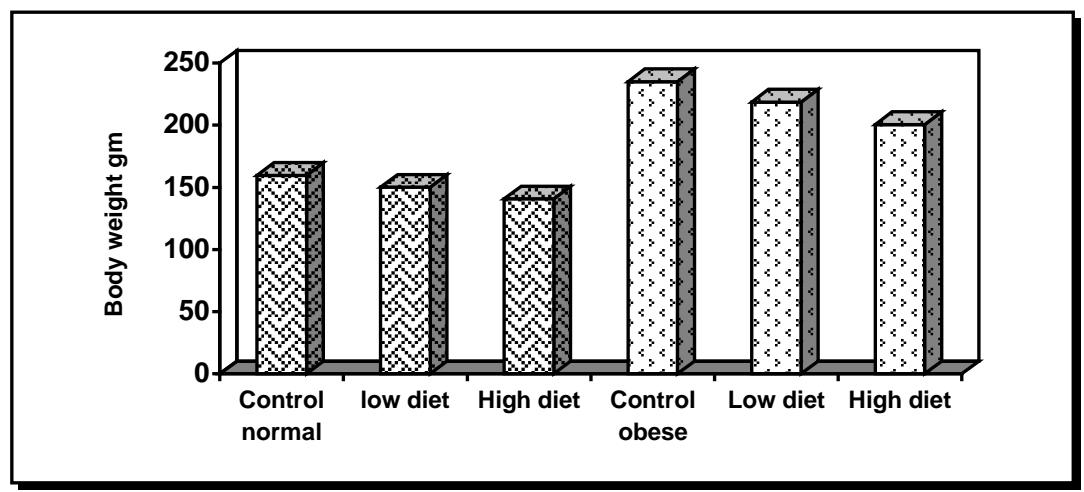

Fig. (5): Effect of low and high lactose diets on body weight (gm) in normal and obese female albino rats

\section{DISCUSSION}

Women in western countries are urged to consume dairy products to enhance their calcium intake, with the aim of reduction in risk of osteoporosis $^{(20)}$. Since lactose is the primary carbohydrate in milk, those who consume large quantities of dairy products ingest large quantities of lactose $^{(21)}$. Lactose is a disaccharide that is hydrolyzed by enzyme lactase into glucose and galactose. In mammals, including humans, intestinal lactase activity is highest during the time of suckling and declines to lower levels after weaning $^{(22)}$. The results of the present study showed that, normal and obese female rats fed by low and high lactose diet for three months, showed decreased serum estrogen and progesterone levels. These results could be explained by that, the ovary has relatively abundant levels of three of the major enzymes involved in metabolism of galactose (galactokinase, galactose-1-phosphate uridyl transferase (GALT) and UDPglactose-4-epimerase) ${ }^{\mathbf{( 2 3 )}}$. This fact was proved by the observation that, women who have absent of low GALT activity, have a propensity to develop premature ovarian failure and premature menopause ${ }^{(7)}$. Also, the deficiency of GALT enzyme induced a lake of UDP-galactose, which is one of the GALT reaction products, and also acting as a substrate for subsequent galactosylation ${ }^{(24)}$. Moreover, the mechanism of ovarian damage have been hypothesized, by the direct toxicity of galactose and its metabolites within the ovary, and became apparent from the toxic observation of the extremely early ovarian failure (before the age of 30years) in women with galactosemia $^{(25)}$. Also, it was reported that, women who consume milk and dairy products in large amounts, have higher incidence of developing cancer ovary or premature ovarian failure ${ }^{(26)}$. In addition, it is possible that, the toxic metabolites of galactose, induced apoptosis of the ovarian tissues, which may be due to an 
imbalance between pro-apoptotic and anti-apoptotic factors of the ovary, after binding of pro-apoptotic factors to specific ovarian membrane receptors ${ }^{(27)}$. The vaginal cytology showed that female rats usually display regular vaginal cycles and after the period of the experiment, they had progressive decrease in the ability to maintain regular estrous cycles ${ }^{\mathbf{( 1 9 )}}$. This may be due to the high levels of FSH which explained the failure of ovarian response to pituitary hormones, irregular estrous cycles and progression of ovarian failure ${ }^{\mathbf{( 2 8 )}}$. It was observed that $40 \%$ galactose diet in rats for two weeks produced inhibition of oocyte maturation manifested by decreased number of coropra lutea, and failure to respond to exogenous gonadotropins. It may be due to an acquired anomaly of the gonadotropin receptors, leading to gonadotropin-resistant syndrome ${ }^{(8)}$. The results showed significant reduction of serum leptin level and body weight. The reduction of body weight may be due to reduction of serum leptin, which is considered as an indirect parameter positively related to the level of body fat ${ }^{(29)}$. This effect of leptin may confirm the antiadiposity effect of lactose ${ }^{(15)}$. Also, reduction of body weight may be due to effect of calcium, the conjugated linoleic acid ${ }^{(4)}$ and leucine $^{(5)}$ content of lactose, with antiobesity action. It was proved by decreased visceral fat accumulation in obese-induced mice with high lactose intake ${ }^{(30)}$. Also, lack of calcium intake may cause obesity, and lack of calcium in adipocytes was related to obesity ${ }^{(31)}$. Moreover, lactose may regulate adiposity via promotion of calcium absorption ${ }^{(6)}$. Also, diets containing $50-60 \%$ lactose result in diarrhea $^{(32)}$, it is possible that dietary lactose may reduce the absorption of diet protein and $\mathrm{fat}^{\left(\mathbf{3}^{3}\right)}$. Lactose also reduced plasma lipids, especially triglycerides and hepatic cholesterol accumulation in hamsters ${ }^{(34)}$.

\section{Conclusion and Recommendation:}

It can be concluded that long term exposure to low and high lactose diets, decreased body weight and cause disturbance of ovarian function and induced cycles irregularity due its galactose content. It is recommended that women with galactosemia and infertility must assess their galactose level which may be the cause of infertility.

\section{REFERENCES}

1. Recker RR, Bammi A, BargerLux MJ, Heaney RP (1988): Calcium absorbability from milk products, an imitation milk, and calcium carbonate. Am J Clin Nutr; 47(1):93-5.

2. McCabe LD, Martin BR, McCabe GP, Johnston CC, Weaver CM, Peacock M (2004): Dairy intakes affect bone density in the elderly. Am J Clin Nutr;80(4):1066-74.

3. Zemel MB, Richards J, Milstead A, Campbell P (2005): Effects of calcium and dairy on body composition and weight loss in African-American adults. Obes Res; 13(7):1218-25.

4. Gaullier JM, Halse J, Høye K, Kristiansen K, Fagertun H, Vik H, Gudmundsen O (2005): Supplementation with conjugated linoleic acid for 24 months is well 
tolerated by and reduces body fat mass in healthy, overweight humans. J Nutr.; 135(4):778-84.

5. Layman DK (2003): The role of leucine in weight loss diets and glucose homeostasis. J Nutr.;133(1):261S-267S.

6. Buchowski MS, Miller DD (1991): Lactose, calcium source and age affect calcium bioavailability in rats. J Nutr.;121 (11):1746-54.

7. Mlinar B, Gersak K, Karas N, Zitnik IP, Battelino $T$ and Lukac-Bajalo J (2005): Galactose-1-phosphate uridyl transferase gene mutations in women with premature ovarian failure. Fertil Steril 84,253-255.

8. Liu G, Shi F, Blas-Machado U, Duong Q, Davis VL, Foster WG, Hughes CL (2005):. Ovarian effects of a high lactose diet in the female rat. Reprod Nutr Dev.; 45(2):185-92.

9. Cramer DW, Harlow BL, Willett WC, Welch WR, Bell DA, Scully RE, Ng WG, Knapp RC (1989): Galactose consumption and metabolism in relation to the risk of ovarian cancer. Lancet.; 2 (8654):66-71.

10. Liu G, Hughes CL, Mathur R, Foster WG, Davis VL, Magoffin DA (2003): Metabolic effects of dietary lactose in adult female rats. Reprod Nutr Dev.; 43(6):567-76.

11. Cooper GS, Hulka BS, Baird DD, Savitz DA, Hughes CL Jr, Weinberg CR, Coleman RA, Shields JM (1994): Galactose consumption, metabolism, and follicle-stimulating hormone concentrations in women of late reproductive age. Fertil Steril.; 62(6):1168-75.

12. Pfeuffer $M$, Schrezenmeir $J$ (2000): Bioactive substances in milk with properties decreasing risk of cardiovascular diseases. $\mathrm{Br}$ J Nutr.; 84 Suppl 1:S155-9.

13. Gong JG (2002): Influence of metabolic hormones and nutrition on ovarian follicle development in cattle: practical implications. Domest Anim Endocrinol.; 23(12):229-41.

14. Reeves PG, Nielsen FH, Fahey GC (1993): AIN-93 purified diets for laboratory rodents: final report of the American Institute of Nutrition ad hoc writing committee on the reformulation of the AIN-76A rodent diet. J Nutr.; 123(11):1939-51.

15. Goseki-Sone $M$, Maruyama $R$, Sogabe N, Hosoi T (2007): Effects of dietary lactose on longterm high-fat-diet-induced obesity in rats. Obesity (Silver Spring); 15(11):2605-13.

16. Ismail AA, Astley $P$, Burr WA, Cawood M, Short F, Wakelin K, Wheeler MJ (1986): The role of testosterone measurement in the investigation of androgen disorders. Ann Clin Biochem.; 23 (Pt 2):113-34.

17. Kulin HE, Santner SJ (1986): The assessment of diminished testicular function in boys of pubertal age. Clin Endocrinol (Oxf).; 25(3):283-92.

18. Spayd RW, Bruschi B, Burdick BA, Dappen GM, Eikenberry JN, Esders TW, Figueras J, Goodhue CT, LaRossa DD, Nelson RW, Rand RN, Wu TW (1978): Multilayer film elements 
for clinical analysis: applications

to representative chemical determinations. Clin Chem; 24(8):1343-50.

19. Cooper R, Clodman I and Vandenbergh $J$ (1993): Monitoring of the estrous cycle in the laboratory rodent by vaginallavage. In: Heindel $\mathrm{J}$, Chapin R (Eds), Female Reproductive toxicity. Academic Press Inc New York, 45-56.

20. Soroko S, Holbrook TL, Edelstein S, Barrett-Connor E (1994): Lifetime milk consumption and bone mineral density in older women. Am J Public Health.; 84(8):1319-22.

21. Niclas $T$, Baranowski $T$, Cullenk and Berenson $G$ (2001): Eating patterns, dietary quality and obesity. J Am Coll Nutr; 20: 599-608.

22. Peuhkuri K, Hukkanen $M$, Beale R, Polak JM, Vapaatalo H, Korpela R (1997): Age and continuous lactose challenge modify lactase protein expression and enzyme activity in gut epithelium in the rat. $\mathrm{J}$ Physiol Pharmacol.; 48(4):719-29.

23. Chavarro JW, Rich-Edwards BA, Rosner W and Willett WC (2007): Diet and Lifestyle in the Prevention of Ovulatory Disorder Infertility Obstet. Gynecol., 110(5): $1050-1058$

24. Lebea PJ and Pretori PJ (2005): The molecular relationship between deficient UDP-galactose uridyl transferase (GALT) and ceramide galactosyl transferase(CGT) enzyme function: a possible cause for long term prognosis of galactosemia. Med Hypotheses; 65:1051-1057.

25. Forges T, Monnier-Barbarino $P$, Leheup $B$ and Jouvet $P$ (2006): Pathophysiology of impaired ovarian function in galactosemia. Human Reproduction; 12(5):573-584.

26. Pfeuffer $M$, Schrezenmeir $J$ (2007): Milk and metabolic syndrome. Obes Rev;8(2) 109-18.

27. Hussin MR (2005): Apoptosis in the ovary: Molecular mechanism. Hum Reprod Update; 11:162177.

28. LaPolt PS, Matt DW, Lu JK (1998): Progesterone implants delay age-related declines in regular estrous cyclicity and the ovarian follicular reserve in Long-Evans rats. Biol Reprod.; 59(1):197-201.

29. Maffei M, Halaas J, Ravussin E, Pratley RE, Lee GH, Zhang Y, Fei H, Kim S, Lallone R, Ranganathan $S$, et al (1995): Leptin levels in human and rodent: measurement of plasma leptin and ob RNA in obese and weight-reduced subjects. Nat Med.; 1(11):1155-61.

30. Sun X, Zemel MB (2004): Calcium and dairy products inhibit weight and fat regain during ad libitum consumption following energy restriction in Ap2-agouti transgenic mice. J Nutr.; 134(11):3054-60.

31. St-Onge MP (2005): Dietary fats, teas, dairy, and nuts: potential functional foods for weight control? Am J Clin Nutr.; 81(1):7-15.

32. Bicudo MH (1993): Effect of lactose induced diarrhea on 
intestinal glutaminase and muscle glutamine synthetase activities in rats. Arq Gastroenterol.; 30 (1):21-6.

33. Leichter $\mathbf{J}$ and Tolensky A (1979): Effect of dietary lactose on the absorption of protein, fat and calcium in the postweaning rat. Am J Clin NUtr; 28:238-241.
34. Hayes KC, Stephan ZF, Pronczuk A, Lindsey S, Verdon C (1989): Lactose protects against estrogen-induced pigment gallstones in hamsters fed nutritionally adequate purified diets. J Nutr.; 119(11):1726-36.

\section{دراسة عن تأثير سكر اللبن( اللاكتوز) على وظائف المبيض ووزن الجسم فى إناث

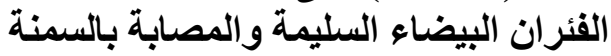 \\ رومبيساء على الثربينى و محمود عبد الحميد الغربيب

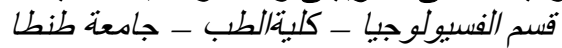

يهذف هذا البحث إلى دراسة التأثير الناتج من تتاول وجبات تحتوى على جر عات صغيرة وكبيرة من اللاكتوز

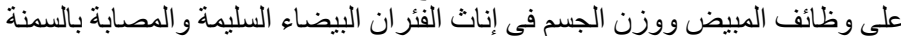

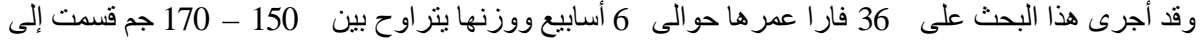
مجمو عتين

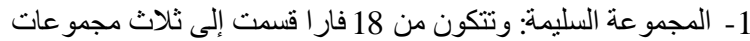

أ - - المجمو عة الضابطة: وتغذت عند على الوجبة الأساسية مضافا إليها 41.9 جم جلوكوز / 100جم من وزن الوجبة لمدة ثثلاث شهو عة المهور.

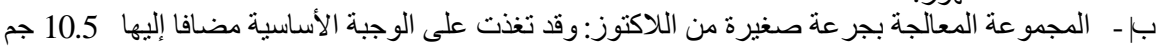

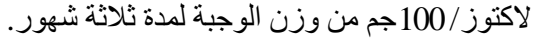

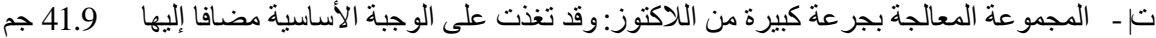

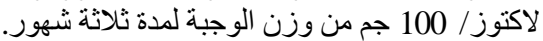

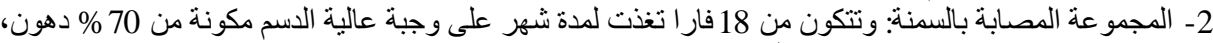

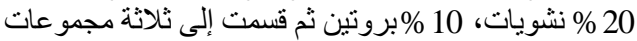

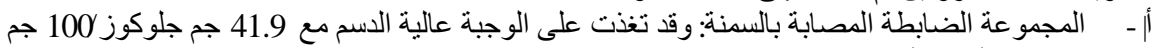

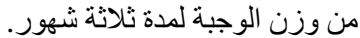

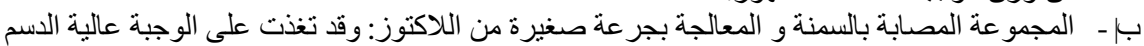

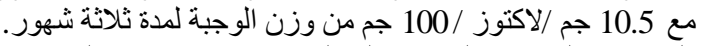

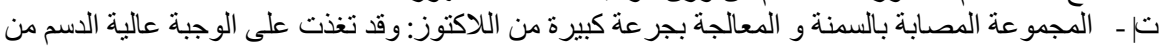

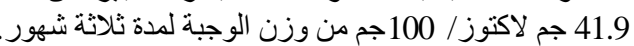

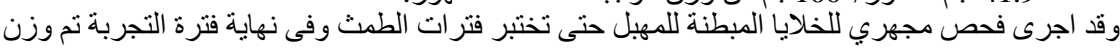

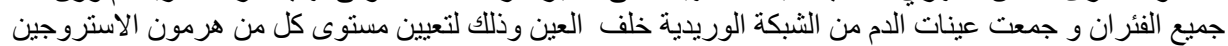

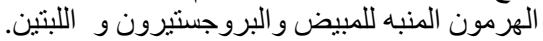

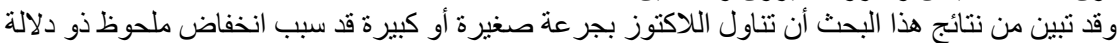

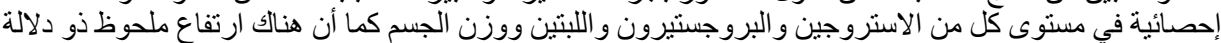

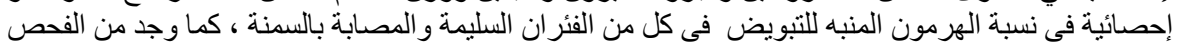

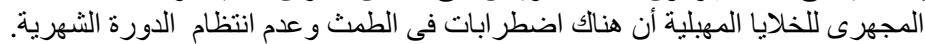

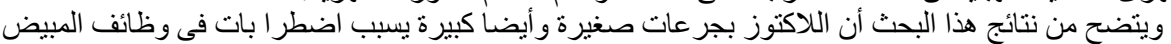

و يسبب نقص فى وزن الجسم وذلك لاحتو ائه على الجلاكتوز.و لذلك ينص ينصح السيدات الاتى تعانى من العقم بقياس مستوى الجلاكتوز لأنه قد يكون سبيا لهذه الحالة. 